\title{
Motivações do conceito de corpo-si: corpo-si, atividade, experiência*
}

\author{
Motivations of the concept of selfbody: selfbody, activity, experience
}

Yves Schwartz**

Université Aix-Marseille - Marselha - França

$\diamond$

Resumo: Este texto busca explicar a função de convergências e questões possibilitadoras do desenvolvimento da tese segundo a qual toda atividade de trabalho é sempre "uso de si, por si e por outros" (SCHWARTZ, 1987). Sucessivas reformulações levaram ao estabelecimento do seguinte princípio: toda atividade industriosa é sempre uma "dramática do uso de um corpo-si" (remetendo "dramática" à necessidade contínua de travar debates com normas). Sendo a atividade humana identificada assim como um contínuo debate de normas cujo lócus é o corpo-si, convém perguntar como, em termos de diferentes medidas temporais, esses debates se encaixam (à maneira das bonecas russas), ou seja, de que maneira as relações valorativas nos meios de vida e de trabalho se incorporam ao âmago do corpo-si, inclusive em termos de temporalidades mais curtas, "escondidas no corpo". Cabe assim entender qual é a unidade enigmática dessa entidade - o corpo-si - que acumula experiência e saberes de formas extremamente diversas, notadamente em sua relação com a linguagem, que articula patrimônio epistêmico e sensibilidade axiológica, sem deixar de estar disponível para ou restrita por micro-escolhas e reajustamentos que a vida não cessa de lhe propor ou impor. O texto, retomando parcialmente, segundo seus objetivos, a distinção entre idem e ipse (RICOEUR), pretende conceber debates de normas encaixados como o cerne da dialética entre essas dimensões.

Palavras-chave: Corpo-si; idem/ipse; Uso de si; Encaixamentos de debates de normas; Dimensões epistêmica e axiológica

\begin{abstract}
This text aims to explain the convergences and questions that made the thesis according to which any work activity is always "use of oneself by oneself and by others" (SCHWARTZ, 1987) to be little by little re-formulated so as to say that "any industrious activity is always a dramatic of the use of a selfbody" (referring "dramatic" to the continuous necessity of doing debates of norms). As human activity is thus identified as a continuous debate of norms whose locus is the body itself, it is suitable to ask how, in terms of different temporal measures, these debates embed (as happens with Russian dolls), in other words, how valorative relations in the environments of life and work are incorporated to the heart of selfbodies, inclusive in terms of shorter temporalities "hidden in the body". We may thus understand what enigmatic unity is that of this entity - the selfbody - that accumulates experience and knowledge in extremely different forms, especially in its relation to language, which articulates epistemic inheritance and axiological sensibility, without stopping to be available for or limited by microchoices and readjustments that life does not cease of proposing or imposing it. The text, retaking partially, according to its objectives, the distinction between idem and ipse (RICOEUR), intends to conceive embedded debates of norms as the kernel of the dialectics between these latter dimensions.
\end{abstract}

Keywords: Selfbody; Idem/ipse; Use of oneself; Debate of norms embedding; Epistemic and axiological dimensions

\footnotetext{
*Tradução de Adail Sobral (UCPel), com atualizações do texto e revisão do autor. Original: Pourquoi le concept de corps-soi? Corps-soi, activité, expérience. Travail et apprentissage, n. 7, juin (SCHWARTZ, 2011).

**Professor Emérito de Filosofia; membro do Institut Universitaire de France, 1993-2003; Diretor Científico do Institut d'Ergologie. Université Aix-Marseille.
} 


\section{Motivações do conceito de corpo-si}

Quando se é levado, no campo intelectual, a criar palavras, para não ser tido por charlatão é necessário indicar por que essa inovação facilita o progresso do criador na trajetória relevante para ele, como ela permite evitar armadilhas advindas do fato de seguir por caminhos já demasiado demarcados nos quais o que se tem a dizer vai se perder. Creio ser esse o caso da noção de "corpo-si": ela veio se impondo pouco a pouco numa dinâmica de produção conceitual no curso da qual vimo-nos diante de inúmeras interrogações e interpelações. Para ser coerente com as sugestões que estas últimas esboçavam e não perder o rumo, nossas trajetórias de tratamento hesitaram em tomar de empréstimo, a quadros teóricos estabilizados, recursos teóricos já usados.

Assim, nesta trajetória de reflexão sobre os processos de "encarnação" manifestos em nossas respostas a solicitações e maneiras de capitalizar os encontros da vida, parece-nos coerente explicitar brevemente como passamos de uma apresentação da atividade de trabalho como uso de si (por outros/por si) à expressão mais completa dramática de uso do corpo-si.

Na origem, no começo dos anos 1980, fomos levados a criar um novo dispositivo universitário de reflexão sobre o trabalho e suas transformações ${ }^{1}$ (denominado então A.P.S.T. ${ }^{2}$ até a criação do Departamento de Ergologia, em 1998), alimentado principalmente pelos encontros com os ergônomos da Escola de Alain Wisner no CNAM (entre eles o saudoso Jacques Duraffourg). Paralelamente, fomos convidados a participar de um seminário coletivo sobre uma questão que surgia com certa saliência no campo da filosofia marxista: a reavaliação da "subjetividade" no processo histórico. A obra publicada em 1987 pela Editions Sociales, Je, sur l'individualité [Eu, sobre a individualidade], foi o resultado de um longo trabalho coletivo sobre essa temática, animado notadamente por Lucien Sève no âmbito do Institut de Recherches Marxistes. Convencidos pela experiência universitária evocada acima, consideramos estratégico valorizar o que nos parecia claro a partir de então: abordando-se o trabalho no micronível, como se sob uma lupa, ou seja, a partir do que passamos a chamar de a atividade de trabalho, esse campo da experiência humana parecia especialmente propício à interrogação sobre a presença enigmática de uma pessoa, de uma singularidade viva no tratamento de situações a viver. Tratava-se de uma visão contrária a uma concepção do trabalho como tempo vendido aos outros, na qual, por isso mesmo, todos se alienavam de si mesmos. Era um duplo desafio: de um lado, se uma filosofia da história se propõe a privilegiar o campo da produção material como matriz de uma dialética histórica, haveria nela uma lacuna caso não incorporasse em sua fabricação da história o nó de contradições que traz todo sujeito da atividade industriosa (a possível contradição entre por si e por outros). De outro, obrigar por esse mesmo motivo certa ideia fraca de cultura a encarar sua incultura especifica quanto à sua abordagem do trabalho humano, contribuindo assim para uma reavaliação de suas verdadeiras dimensões. Travail et usage de soi [Trabalho e uso de si $]^{3}$ foi nossa contribuição a essa obra coletiva.

Não figurava nesta última expressão a dimensão explícita do envolvimento do corpo. Tratava-se de um paradoxo: a generalização filosófica implicada pelo título dessa contribuição resultava amplamente, no entanto, de estudos de situações industriais nas quais os gestos e o engajamento dos corpos eram massivamente mobilizados. Essa extrapolação da fórmula "trabalho como uso de si" a toda forma de atividade industriosa humana era sustentável (a partir dos ensinamentos dos ergônomos ou, de outras maneiras, de Ivar Oddone, ${ }^{4}$ deveras polarizados na época, tanto uns como os outros, nas linhas de montagem) a partir de um raciocínio $a$ fortiori, advindo, nesse tipo de configuração produtiva, de uma redescoberta da experiência operária ou do trabalho real. Não vamos nos deter nessa constatação, já tantas vezes desenvolvida, uma vez que no próprio plano em que os atos operatórios são os mais prescritos, rígidos, aparentemente sem permitir nenhum desvio personalizador, tendo por paradigma situações governadas pela organização científica do trabalho, permanece sempre na penumbra ou na invisibilidade "uma demanda especificada e incontornável feita a uma entidade em alguma parte da qual se supõe haver uma livre disposição de um capital pessoal. É essa a justificativa da palavra 'uso' e a forma indiscutível de manifestação de um 'sujeito"” (SCHWARTZ, 1992 [1987], p. 53). ${ }^{5}$ Se mesmo onde só se deveria observar o uso de si por outros (sendo os conjuntos operatórios prescritos o ponto extremo e o mais próximo do agir industrioso mesmo no conjunto das normas que enquadram o trabalho em empreendimentos dessa natureza), ainda se verifica, sem a mínima dúvida possível, o "uso de si por si" (aquela demanda especificada e incontornável), com ainda maior razão nenhuma outra atividade industriosa humana, necessariamente menos rígida que aquela, não poderia estar desprovida deste último.

\footnotetext{
Cf. SCHWARTZ et FAÏTA, 1985. Sobre a história dessa criação de 1983 a 2009, cf. SCHWARTZ, 2009.

2 A.P.S.T.: Analyse Pluridisciplinaire des Situations de Travail [Análise Pluridisciplinar de Situações de Trabalho]

3 SCHWARTZ, 1987.

4 Cf. ODDONE et al., 1981

5 Sobre esse raciocínio a fortiori, a partir do exemplo clássico de uma operadora de fabricação de componentes eletrônicos, nossa apresentação mais didática está em SCHWARTZ et DURRIVE, 2003, p. 21-30.
} 
Por que "si"? A escolha das palavras na fórmula geral do trabalho como "uso de si" se arraiga adequadamente, apesar do paradoxo, no encontro privilegiado do mundo industrial e operário: essa tentativa de recentramento do meio em torno de normas próprias da pessoa no trabalho nos parecia uma enigmática busca das exigências da vida em nós (busca na qual se reconhecia toda a força do legado de G. Canguilhem, especialmente 1966) principalmente porque o corpo vivo não poderia ser expulso desse esforço. Isso se sustenta mesmo que afirmássemos claramente que esse corpo vivo era ao mesmo tempo corpo de um ser psíquico e histórico. Como então qualificar a base desse "recentramento", que não podia, portanto, restringir-se à "alma", se ela não podia ser apenas o "corpo"? Foi para evitar inserir esse esforço de recentramento nas problemáticas demasiado codificadas do "sujeito", da "subjetividade" (que envolvia o risco de neutralizar a dimensão de uma busca da vida em nós) que preferimos usar o termo voluntariamente obscuro "si".

A participação predominante, em nosso "dispositivo A.P.S.T", de interlocutores que atuavam no setor de "serviços", termo extremamente ambíguo, cabe admitir, mas que conota uma profunda transformação tendencial nas maneiras sociais de trabalhar e de produzir, teve um duplo efeito aparentemente paradoxal.

O primeiro nos levou a apontar uma dimensão do agir particularmente inescapável quando as pessoas humanas são o horizonte indireto ou direto do uso de $s i$ industrioso. Essa arbitragem entre o uso de si por si e por outros implica forçosamente uma escolha, por ínfima que seja, incidente sobre a sequência de vida de outras pessoas, cujas modalidades de uso de seu tempo de vida é assim levado em conta de modo variável por esse "si" industrioso. Quando uma pessoa, mais ou menos sob pressão, envia a um usuário uma pasta formalmente "incompleta" ou, pelo contrário, decide completá-lo com elementos de que já dispõe, utilizando um tempo adicional necessário, a presença desse usuário em sua deliberação invisível é forçosamente marcada de uma dada maneira, com graus variáveis de proximidade em termos de valor. A pessoa em questão faz uma escolha de ato de trabalho de que não se podem excluir as modalidades da incidência sobre ela de um universo de valores que integram de maneiras variáveis a outra num hipotético mundo comum. O fato de um funcionário no guichê decidir ou não elevar a voz, falar ou não mais devagar, diante de um cliente com claras dificuldades com a língua local e outros casos desse tipo são escolhas imperceptíveis que nada têm de neutras, ainda que não possam ser avaliadas e julgadas fora das restrições do meio.

É claro que essa dimensão axiológica, de um debate de si consigo no eixo de um mundo de valores sempre em (re)construção nunca esteve ausente das situações da atividade industriosa, inclusive no âmbito da produção material e de uma organização tayloriana do trabalho. Por trás da relação "manufatureira" com a matéria, há sempre escolhas de uso industrioso pela atividade humana (cf., em SCHWARTZ; DURRIVE, 2003, p. 29-30, a quarta proposição extrapolada a partir das constatações ergonômicas sobre a separação entre prescrito e real no caso de uma operadora de uma cadeia de produção de componentes eletrônicos: a gestão da separação "remete a um debate de valores").

Seja como for, a proliferação das atividades ditas de serviço obriga a enfrentar de modo bem mais direto uma dimensão em geral bem invisível do trabalho: toda sequência de atividades industriosas envolve arbitragens, debates, imersos num mundo social em que a comunidade de destino é sempre eminentemente problemática, em permanente reconstrução. Advêm dessas arbitragens decisões sempre parcialmente não antecipáveis, "renormalizações"; mesmo num nível infinitamente pequeno, os resultados dessas arbitragens as "renormalizações" - recriam sem cessar uma história: "ocorre continuamente algo novo" que, obrigando-nos a escolher, forçam-nos a nos escolher, na qualidade de seres às voltas com um mundo de valores. Daí vem a ideia de que esse uso de si é uma imposição contínua dessas micro-escolhas permanentes e disso surge a expressão do trabalho como dramática do uso de si. ${ }^{6}$ Por fim, a atividade industriosa se torna cada vez mais um encontro de dramáticas do uso de si, a de um agente no trabalho e a do usuário, do cliente, do paciente, do aluno etc.

O segundo efeito aludido parece contrário ao primeiro: se aquele insistia numa tendência particularmente clara no chamado setor de "serviços", este, inversamente, foi levado a recusar uma diferença de natureza, com frequência instituída, entre o trabalho manufatureiro, industrial, em que a produção material é a meta do resultado industrioso, e o envolvimento do corpo é dominante, e o trabalho nos serviços, em que, ao contrário, a presença do corpo no agir parece secundária. Claro que se sabe muito bem que a distinção serviços/produção é cada vez mais discutível, inclusive no âmbito do chamado setor produtivo, graças às tantas formas de gestão informatizada da produção. Mas subestimar o corpo em ação nas atividades de serviço comportava um duplo risco: não entender a verdadeira natureza do uso de si nesse tipo de atividade; criar uma dicotomia, prejudicial do ponto de vista antropológico, entre dois usos da atividade industriosa humana - um em que o corpo é ativo diante da matéria inerte e outro no qual as conexões nervosas cerebrais são mobilizadas em

\footnotetext{
6 Dramática remete à ideia de sequências de vida em que aparece o inantecipável, a história, e não necessariamente a uma provação, uma tensão dificilmente suportável, embora este possa ser de fato o caso (cf. SCHWARTZ et DURRIVE, 2009, Dialogue 1, p. 26-30).
} 
seu confronto com um campo social imaterial, supondo-se que o corpo físico aí permanecesse relativamente inerte e intercambiável. Se o primeiro efeito indicava diferenças tendenciais, o segundo, ao contrário, pretendia juntar as várias peças.

Manifestar a onipresença de um corpo no trabalho em atividades dos chamados serviços nos pareceu então uma exigência filosófica e operacional fundamental. Manter a dicotomia seria destruir a unidade de um projeto perseguido ao longo da história da humanidade: a tentativa do ser vivo de recentramento das restrições e recursos dos meios de vida em torno de suas próprias normas históricas de vida e de saúde. Essa tentativa de viver nos parece estar presente a todas as formas técnicas e sociais inventadas no curso da história. É ela que é sancionada em seus êxitos e fracassos; é mediante essa dramática global que se podem avaliar as questões de saúde e de patologia industriosa. Imagina-se a que cegueira quanto à administração do trabalho pode levar a subestimação desse envolvimento, de seu custo em termos de tensão tanto nos trabalhos denominados falsamente "manuais" como nos ditos "intelectuais". Justo por se levar em conta o peso da gestão das dramáticas da atividade nos "serviços" é que não causa surpresa que eles sejam hoje um lócus privilegiado de proliferação de "riscos profissionais vinculados com fatores psicossociais".

Mas qual poderia ser o suporte dessa gestão de arbitragens senão o mesmo ser "encarnado" cuja relação polarizada em termos de valor com os meios de trabalho não cessa, do começo do Paleolítico ao universo das tecnologias e redes atuais, de anunciar seu vir-aser humano? Era portanto imperativo restaurar uma continuidade das atividades de serviço com os tipos de atividade em que essa "encarnação" é evidente (o processamento industrial da matéria). Claro que é bem mais difícil de sugerir, nos diversos tipos de atividades de serviço, a infiltração desse valorar o meio a viver no seio de todas as dimensões do corpo, mas esse é um desafio que se pode vencer.

Já destacamos, a propósito dos "ingredientes da competência", essa dimensão incorporada da competência, que supõe um grau de maestria dos modos de infiltração do histórico numa situação de trabalho, condicionando a gestão apropriada desta. (Lembremos que, no âmbito do debate aberto a partir dos anos 1990, sobre as noções de qualificação e competência, com a mobilização de "lógicas das competências" nas empresas e das planilhas de quantificação das competências, propusemo-nos a abordar o "agir competente", tanto no trabalho como, para além dele, como uma sinergia sempre problemática de ingredientes de natureza heterogênea. Desse ponto de vista, nenhum método único que suponha um conceito unificado de competência nos pareceu capaz de servir de base à avaliação desta (cf. SCHWARTZ, 1998). O que passamos então a chamar de segundo ingrediente da competência (cf. SCHWARTZ, 2000 [1996], texto 24 , p. 487-491), aquele por meio do qual o tratamento da atividade local se arraiga na singularidade e na historicidade de uma situação, requer a onipresença de um si que é fundamentalmente também um corpo. E esse segundo ingrediente, com suas especificações relativas, é imperiosamente exigível na gestão de situações de "serviço". Atender uma fila de clientes supõe por exemplo - com uma intensidade variável de acordo com as normas que cada pessoa específica vai seguir - de captar todo tipo de indicações, de acompanhar em tempo real um "clima" humano microssocial, mobilizando permanentemente os cinco sentidos. Isso supõe deslocar o olhar, a cabeça, o corpo, de modo mais ou menos imperceptível se a pessoa desejar manter na invisibilidade seus microprojetos de tratamento da situação: avaliar a tensão de alguém (a impaciência dos clientes eventualmente aumentada por pessoas cuja instabilidade pode ser percebida mediante vários signos corporais ou agravada por condições de trabalho complicadas num dado dia) e conter a sua própria impaciência recorrendo a mediações neurofisiológicas cujos segredos nos escapam em larga medida.

A propósito dessa forma de competência dita "aderente" ao agir, Jacques Leplat fala justamente de "competências incorporadas". ${ }^{7}$ Essas captações de informações in situ que favorecem arbitragens industriosas apropriadas (não apenas à situação como às escolhas pessoais de tratamento da dramática) pouco diferem das "observações sintéticas" observadas pelos ergônomos entre, por exemplo, operadores que controlam o andamento em indústrias de processamento. Há sem dúvida a presença do corpo que sente e vigia, que adere a, e seleciona, parâmetros variáveis da situação. Falamos intencionalmente de seleção: o projeto de recentramento, isto é, polarização valorativa da relação com o meio a viver se infiltra por todos os circuitos do corpo, e é bem esse elemento, recordemos, que justifica falar de uma continuidade do agir industrioso em suas distintas formas técnicas e sociais. No caso das atividades evocadas, as escolhas de dados a considerar, que exprimem essa polarização valorativa, mobilizam a postura, a gestualidade, a forma de abertura ou fechamento diante do outro. Em suma, é o conjunto de recursos de nosso corpo que sustenta essa relação polarizada, e não simplesmente nossos cálculos intelectuais, e isso explica a possibilidade de estarmos fisicamente esgotados ao final de uma jornada de trabalho nesse tipo de atividade.

Pensemos num confronto entre um usuário e um Consultor de Reinserção Profissional, no qual se percebe

\footnotetext{
7 Éducation Permanente, n. 123, p. 101 s.
} 
como esse "encontro de dramáticas de si" atravessa e se apossa do corpo: "as expressões do olhar, a postura e a direção do olhar testemunham o interesse ou desinteresse do usuário diante de uma proposta. Esses gestos são com efeito escolhas, processos de renormalização, porque sua percepção pelo Consultor leva este último a reajustar as soluções propostas, que também serão reavaliadas pela percepção de novos microgestos. O mesmo ocorre com o Consultor, que exprime com seus microgestos seus projetos e valores. Se considerar que um dado tipo de contrato de trabalho não vai contribuir para melhorar a situação do usuário, o Consultor vai exprimir mediante microgestos seu ponto de vista, pelo tom de voz, digamos." 8

Mesmo quando as formas do trabalho parecem prescindir do invólucro corporal, como no caso em que o único veículo e ferramenta de consumação da atividade industriosa é a linguagem (por exemplo, as formas de teletrabalho), é no entanto através de uma sinergia quase invisível, uma punção escura em todos os recursos localizados no seio deste invólucro, que a produção se realiza. Josiane Boutet afirma, nas belas páginas de $L a$ vie verbale em travail [A vida verbal no trabalho], que "Pensar o trabalho de linguagem como algo imaterial dificulta conceber a importante especificidade desses ofícios: a atividade de linguagem dos assalariados é a um só tempo um fator de produtividade e uma atividade de produção". A flexibilidade de uso, os milhares de modulações possíveis, fonológicas, semânticas e outras, que a linguagem possibilita se produzem no ponto extremo de um cálculo intelectual cujas trajetórias de eficiência recorrem a um obscuro "agir conjunto" de um corpo histórico no trabalho:

O trabalho de linguagem no setor de serviços constitui uma atividade perceptiva e motriz que envolve o corpo dos assalariados com sua laringe, sua voz, sua capacidade auditiva e, ao mesmo tempo, uma atividade de cunho intelectual que mobiliza suas competências gráficas, suas competências discursivas, a qualidade de sua colocação de palavras nos diálogos, suas habilidades argumentativas. (BOUTET, 2008, p. 87) ${ }^{9}$

Como memorizar, organizar, hierarquizar, de modo imaterial, saberes, gestos, procedimentos a reatualizar no momento oportuno? Como gerir os graus de esquecimento necessários para enfrentar situações que sempre mesclam o típico e o singular? Que se faz para gerir a fadiga ao longo de uma jornada de trabalho? Há toda uma "composição" do corpo que cada um deve fazer com seus históricos, seus pontos fortes, suas fraquezas.

Um dos aspectos mais salientes desse engajamento do corpo em atividades consideradas "não-corporais" é considerado por estudos recentes sobre distúrbios musculoesqueléticos e o efeito provável do que chamamos de dramáticas do uso de si na produção desse tipo de alteração. ${ }^{10}$ Como se modulam essas enigmáticas sinergias, a serviço de estratégias mais ou menos claras ou obscuras para a consciência com o passar dos anos? Como um corpo sexuado ajusta sua diferença e seu modo de ser sexuado para realizar sua gestão de situações num meio de trabalho em que essa dimensão permanece na penumbra sem nunca ausentar-se?

Recorrendo a essa estranha entidade, suporte de nossa polarização valorativa de nossos meios de vida (como os meios de trabalho), que caixa de Pandora destapamos?

De um lado, cremos poder afirmar que o trabalho como uso de si é uso de um corpo-si. Com efeito, o essencial nessa fórmula, o debate entre o uso de si por si e o uso de si por outros, a inevitável arbitragem, e, portanto, a presença de valores que possibilitam as escolhas, as resultantes das dramáticas em termos de recentramentos, "renormalizações", investem e se infiltram nos circuitos hierarquizados do agir que há em nosso corpo. Um mundo de valores, termo eminentemente obscuro mas cuja presença em nós é indubitável, ${ }^{11} \operatorname{logo}$, um mundo em desaderência com relação a nossa presença no mundo hic et nunc, se dissemina em nossas conexões nervosas e fibras musculares para impor normas ao nosso agir. ${ }^{12}$

De outro, essa "união alma-corpo", para falar como Descartes, não pode, como ele mesmo o reconhecia tão precisamente, ser objeto de nenhuma "ideia clara e distinta". Como ele disse à Princesa Elisabete da Boêmia, não tente compreender, com a ajuda da ideia de união da alma e do corpo, como a alma "tem o poder de mover o corpo". Parece-nos sobremodo significativo que seja nesse momento de uma tentativa de pensar o "agir conjunto" do material e do imaterial que há em nós, que, pela primeira vez na filosofia, o obscuro se torne uma norma de pensamento: "as coisas pertinentes à união da alma com o corpo só obscuramente são conhecidas pelo puro entendimento". ${ }^{13}$

Não há domínios definidos e circunscritos em que se possa tratar de maneira segmentada uma dimensão desse agir conjunto. Por isso, nenhuma disciplina acadêmica,

\footnotetext{
8 Sabine Lauroua, 2004. Cf. tb., nesse mesmo sentido, o trabalho de Françoise Lima, 1996, in SCHWARTZ, 2000, p. 36.

9 Aproveitamos esta ocasião para destacar as profundas convergências, no tocante às relações entre a abordagem ergológica e os estudos da linguagem, inspiradas seja em Bakhtin, Benveniste ou Maingueneau, tais como desenvolvidas pelas colegas brasileiras Maria da Gloria di Fanti (2013), Marlene Texeira (2013), Cécilia Souza-e-Silva e Raquel Motta (2013).

$10 \mathrm{Cf}$. as importantes contribuições de F. Daniellou, esp. 2008

11 Cf. SCHWARTZ et DURRIVE, 2009, p. 61-80.

12 Alguns trabalhos do campo das atividades físicas e esportivas são bem eloquentes quanto a isso. Cf. Michel Récopé, 2011. E a tese de Hélène Fâche (2011).

13 Cartas de Descartes a Elisabeth. 21/05/1643 e 28/06/1643. Cf. quanto a isso SCHWARTZ, 2007, p. 125.
} 
das neurociências às ciências políticas, passando pela psicanálise, e, mais do que isso, nenhuma tecnologia de organização humana da atividade (industriosa), pode pretender se apropriar dessa entidade (ou de parte dela) em seu enfrentamento dos encontros da vida e conceber "a ciência" dela.

Globalmente, essa entidade que passamos a chamar de "corpo-si" transgride todas as fronteiras entre o biológico e o histórico. Ou, mais do que isso, ela historiza o suporte biológico sem que por isso autorize a dissociar esse esforço de recentramento, que se poderia também chamar de busca de saúde, de seus legados imemoriais arraigados no vivo em geral. Esse si é portanto um sábio "desconhecido", para retomar uma fórmula de Nietzsche, justo por ser um corpo-si. ${ }^{14}$ Ele traz em si uma tríplice ancoragem:

- biológica: esse corpo dado no nascimento, com suas potencialidades e seus limites, traz uma busca de saúde ainda genérica e indeterminada;

- histórica: mediante o debate de normas (por si/por outros) que constituem a própria substância dessas dramáticas e só adquirem sentido num momento particular da história;

- singular: na experiência de vida de cada pessoa, cuja negociação de dramáticas próprias opera como agir de um corpo físico pessoal, um corpo desejante, em permanente tentativa de "composição" e de apropriação desse seu suporte de vida, a fim de responder aos encontros e provas. É no cerne desse corpo-si singular que se infiltra a relação variável de cada um com um "mundo de valores" que vai além dele, mais ou menos, a depender da pessoa.

Três ancoragens absolutamente indissociáveis. Trabalhar é então tentar estabelecer uma sinergia para essa tríplice ancoragem no tratamento dos debates de normas que se fazem incessantemente presentes em nossos encontros industriosos.

\section{A atividade como debates de normas encaixados}

É necessário sugerir agora uma dimensão, ou melhor, uma escansão temporal para essa tentativa permanente do corpo-si no sentido de viver em saúde a relação com seu meio a viver.

Antes de tudo, caracterizamos essa tentativa como sequência de debates de normas. Parece-nos que ela deve ir além da arbitragem: uso de si por si/por outros. Recordemos por que há uma inelutável sucessão de debates de normas: temos de agir num mundo que não criamos, saturado portanto por inúmeras normas antecedentes de diversos níveis e graus de proximidade com as exigências do presente. Ora, dissemos que era a um só tempo impossivel e invivível a submissão desse nosso agir ao controle estrito por essas normas antecedentes. Disso vem a necessidade de nos proporcionarmos normas parciais, reajustadas no instante do agir, para lidar com "a" situação. Nossa vida é em consequência uma sequência de debates de normas, exigidos pela configuração normas antecedentes, de um lado, e impossível e invivível, do outro, que desembocam na série de resultantes que denominamos "renormalizações". 15

Pois bem. Mas o que liga os diferentes debates? Trata-se de uma questão de unidade da experiência, na qual podemos reler uma versão bem diluída da unidade originalmente sintética do sujeito transcendental kantiano. Como pensar a relativa singularidade de um debate de normas próprio a um instante particular, e sua inclusão mais ou menos coerente ou perturbadora num debate de normas cujo horizonte temporal é mais amplo, diante de uma situação de maior amplitude em que se insere mais ou menos a situação precedente? Vivemos um patchwork incoerente de debates e de renormalizações? É assim que vivemos? Como esse encaixamento ${ }^{16}$ de inclusões parciais, que devemos supor porque existe nossa experiência de vida, seria possível, no próprio suporte desses debates, ou seja, nosso corpo-si? Estamos diante do problema do encaixamento parcial de debates de normas.

Assim, uma dada pessoa pode "renormalizar" seu emprego do tempo de uma jornada de trabalho hierarquizando à sua maneira as diversas tarefas que se espera que essa pessoa realize (normas antecedentes), segundo suas próprias normas de apreciação das dificuldades, de avaliação mais ou menos crítica do uso que se espera dela, e de preservação de seus recursos físico-mentais. Mas, no curso dessa jornada parcialmente recentrada em torno de normas próprias da pessoa, ligações telefônicas, visitas, dificuldades ou oportunidades

\footnotetext{
${ }^{14}$ Cf. SCHWARTZ 1992 (1987), p. 57-58, e 2010, p. 19-21. Faz-se uma breve alusão neste último texto a "três médicos atípicos", de que falamos muitas vezes alhures, a saber, Canguilhem, Wisner e Oddone, que nos levaram enfaticamente a defender essa concepção ampliada de busca de saúde.

15 Cf. esp. SCHWARTZ, 2010, 2007, 2000, p. 598-605 e SCHWARTZ et DURRIVE 2009, Dialogue 2 e Manifeste pour un ergoengagement [Manifesto para um ergoengajamento]. Há um ponto importante a observar: M. Merleau-Ponty é uma referência rica e obrigatória para toda consideração do corpo próprio, a indistinção "alma corpo" de nosso ser no mundo. Tememos ser injustos não the reconhecendo o peso que lhe cabe nessa difícil tentativa de dizer o obscuro e talvez indizível. Para compensar, diríamos que é precisamente por que nosso ser no mundo tem uma relação ab initio polêmica, mediada por esse dimensão de debate de que essa fenomenologia do corpo próprio (ainda?) não nos convenceu. Estamos bem inclinados a ver nisso a separação entre Merleau-Ponty e Canguilhem, apesar de os dois serem grandes leitores de [Kurt] Goldstein [Neurologista e psiquiatra alemão, pioneiro da neuropsicologia moderna. N.T.]

16 Usamos o termo "encaixamento" em analogia com as famosas bonecas
} russas, que são encaixadas uma no interior da outra. N.A./N.T 
imprevistas podem levá-la a incluir sequências de debates de normas de "nível inferior" no âmbito desse recentramento inicial, se for possivel. Porque pode ocorrer que as escolhas surgidas desses microdebates perturbem, ou seja, levem a reconsiderar parcialmente a coerência organizadora desse recentramento inicial.

Pode-se assim pensar numa dinâmica de encaixamentos problemáticos, ao ponto de indefinição, ao ponto de movimentos oculares específicos, totalmente não percebidas por nós, sem no entanto estar desconectadas das escolhas de "Si", como diria Alain Berthoz. ${ }^{17}$

Do mesmo modo, um vigia pode selecionar uma indicação auditiva (ruído de uma válvula), mais do que visual (o aspecto de um jato de vapor) num dado momento da vida de uma instalação, considerando-se aquilo que ele sabe - ou sente - sobre a condição da instalação num dado momento e do grau de apropriação como sua dessa instalação. Um recentramento de ampla duração da relação de sua vida com a instalação, como forma de "projetoherança" 18 pode incluir microdebates de normas relativos às escolhas de informações a considerar com seus cinco sentidos. Um debate de normas que seria bem distinto do de um novato, no mesmo momento e ambiente, menos implicado com a segurança da instalação. Isso supõe que nosso corpo-si, em todos os níveis entre a consciência e "as profundezas do corpo", internaliza processos de seleção de informações pertinentes, determinando e hierarquizando esses debates de normas, infiltrando os efeitos de relações valorativas em situações de amplitude variável, inclusive infinitesimais.

É nesse sentido que "extraímos" a noção de "corpo produzido" cuja gênese Canguihem evoca a partir do "corpo dado", em Écrits sur La Médecine [Escritos sobre a Medicina] (2002 [1990], p. 58-63). E a atividade humana (cf. Idem, p. 59, $\S 3^{\circ}$ ) nos parece a tentativa permanente de dar coerência aos encaixamentos de debates de normas, com todas as formas de fracasso parcial ou total de que certas tragédias atuais do trabalho nos oferecem formas particularmente preocupantes.

Pesquisas do campo da psicologia cognitiva e das neurociências mostram-se assim indispensáveis para testar nossas hipóteses. Nesse sentido, muitas vezes nos

\footnotetext{
17 Cf. BERTHOZ, 1997, p. 287.

18 Cf. SCHWARTZ, (1988) 2012, p. 481-48. Dissemos ali que em todo meio de trabalho, desde que haja certa estabilidade na duração, coexistem e até se enfrentam, entre seus diversos protagonistas, diversas formas de valorização da história desse meio (uma empresa, um estabelecimento, um serviço...), alimentando variados engajamentos, iniciativas e projetos no seio desse meio. Reciprocamente, e engajamentos e iniciativas levam a escolher, valorar, triar no passado do meio aquilo que legitima essa dimensão de projeto.

19 Bem próximo, acreditamos, daquilo que Récopé et al. (2011) chamam de sensibilidade $a$.

20 Pode-se sem dúvida pensar nas diversas redefinições e recomposições entre atividade, ação e operação na obra de Leontiev (p. ex., 1984, cap. 3, seção 5.)
}

perguntamos sobre o vínculo entre memória de trabalho e memória no trabalho. A memória de trabalho se mostra como extensão da memória imediata; ela "organizaria um número relativamente significativo de capacidades temporárias, cada uma delas dependente de um dos sistemas cerebrais especializados no tratamento de uma informação" (SQUIRE; KANDEL, 2002, p. 107). Deve-se manter esse material no lobo frontal "para uma utilização temporária", para "orientar o comportamento e a cognição", em suma, para poder agir (o que constitui memória de trabalho) mediante a integração de elementos voltados para esse objetivo. Mas de onde vem esse esforço top-down de manutenção da atividade neuronal nas áreas sensoriais durante um espaço de tempo, por certo bem curto, mas suficiente para integrar aí os dados e assim possibilitar o agir, apesar de eventuais "distratores" (idem, p. 108), essa disponibilidade certamente hierarquizada em favor de certos tipos de informações sensoriais? Aquilo que consideramos uma seleção, uma hierarquização, diferentes de sujeito para sujeito, é tido pelos autores citados, que são psicólogos, como advindo da "atenção, motivação e orientação geral do comportamento" (ibid.), termos genéricos de sua disciplina. Em nosso caso, diríamos, para "reinserir na história" esses esforços e hierarquizações, que é justo a partir desse tipo de "projeto-herança", de relação valorativa global19 com o meio presente hic et nunc, que se pode levantar uma multiplicidade de início não hierarquizada de dados sensoriais (ver o exemplo do vigia e no novato acima), e que essa relação global é que vai permitir a seleção. Se esse projeto-herança ancorado numa memória de longo prazo opera escolhas acerca daquilo que a memória de trabalho deve selecionar e conservar no lobo frontal, seria talvez possível falar de um vínculo estreito entre memória de trabalho e memória no trabalho.

Dessa maneira, seria possível compreender o corposi como um todo em confronto "ativo" com um meio ecológico-social. No âmbito de projetos-herança de intervalos temporais relativamente amplos, relativamente estabilizados, embora sempre disponíveis a dramáticas de renormalização de diversos níveis, se encaixariam com graus variados de coerência debates de normas, projetos-herança de temporalidades e amplitudes mais reduzidas, chegando ao "escondido no corpo", o chamado gesto "habitual", chegando a subsumir em parte os processos instantâneos da memória de trabalho. Mas com a eventualidade permanente tanto de uma recomposição entre os diversos níveis de projetosherança ${ }^{20}$ como, de modo mais crítico, o risco de um encaixamento imperfeito, ou mesmo de uma coerência impossível entre as renormalizações a realizar (o que, num certo nível de consciência, se pretende designar pela expressão significativa mas ambígua "atividade 
contrariada". ${ }^{21}$ Trata-se de uma situação que pode, no melhor dos casos, renovar a memória de longo prazo, reativar os projetos-herança de nível superior (o que nunca é apenas um processo individual), mas também levar ao impossível confronto com a situação (de trabalho) a viver, aos fenômenos que alguns chamam de "sofrimento" (no trabalho). Esse fracasso de uma busca de coerência atravessa, inserido em projetos-herança de longa duração, todas as configurações de vida de um corpo-si, e, por exemplo, em nossas sociedades, em que ainda funciona, em redes sobremodo trançadas, a distinção "trabalho/fora do trabalho", essa frágil cesura entre vida pessoal e vida profissional.

A noção de "encaixamento" funciona em consequência para nós como tentativa de sugerir de que maneira se insemina no mais profundo de nosso corposi nossa relação valorativa, constituindo-se a mediação por combinações problematicamente hierarquizadas de debates de normas, debates que, em todos os níveis, só podem ser resolvidos pela arbitragem de uma verticalidade axiológica. Temos estado às voltas há algum tempo com esse tipo de exigência (cf. p. ex. SCHWARTZ, 2000, p. 318-319, Conclusion, seção 1.3 a 1.6, seção 2.3). Quando nos questionamos sobre o conteúdo do que poderia ser a "competência" (no trabalho), não conseguimos evitar, como evocamos acima, decompô-la em ingredientes completamente heterogêneos (6) cuja colocação problemática em sinergia advém a cada momento das singularidades do encontro de uma pessoa com uma situação (cf., idem, 2000 [1999], texto 24). Um dentre eles, o ingrediente 2, já mencionado, nos obriga a integrar, àquilo que nos torna "competentes" numa dada configuração sociotécnica, a mobilização de circuitos do corpo-si cuja operatividade nos escapa em margens imprecisas, em proveito de renormalizações de temporalidade ampla que chamamos de "projetosherança":22

Essa onipresença de um corpo, de um "corpo-si", nas circunstâncias da gestão eficaz de situações, é o que manifesta mais claramente a ancoragem

\footnotetext{
${ }^{21}$ Aquilo que Hartmut Rosa denomina a aceleração do tempo leva sem dúvida a recompor a hierarquia de usos de nosso tempo e corre assim o risco de destruir em parte a relação entre essa hierarquização e os valores que a organizam - o que não deixa de ter efeitos patogênicos. Essas "relações consigo", que são projetos-herança, constituem de fato relações com o tempo, havendo um grande risco de a recomposição mais ou menos restritiva das sinergias ser patogênica (cf. ROSA, 2005, p. 169,181$)$.

22 Remetemos às páginas igualmente cativantes de Michel Jouanneaux, piloto comercial, que reflete sobre as dimensões incorporadas de suas escolhas no agir profissional, p. ex, 1999, p.215-225, e, de modo ainda mais argumentado, em De l'Agir au Travail (2011, Octarès éditions), sobre a maneira como a restrição de ser e agir no presente convoca, nos circuitos do corpo, para retrabalhá-los, os diferentes níveis do afetivo e do pensar.
}

singular, histórica, desse ingrediente. Com efeito, esse "corpo-si", que negocia, incorpora pontos de referência, valores, é sempre um corpo próprio, apreendido no eixo de uma biografia singular. Não há como dois corpos se "domesticarem" do mesmo modo, não articulam na enigmática de seu ser as mesmas informações, as mesmas restrições, as mesmas maneiras de "combater o esquecimento”, por exemplo. (Ibid., p. 490)

Evocamos um exemplo marcante advindo dos trabalhos de nosso amigo e colega Pierre Trinquet: por que um pedreiro ouve o ruído de uma grua num canteiro de obras e se precipita para ajudar seus companheiros, quando o pesquisador, vindo do mesmo meio profissional, nada ouve nem entende esse gesto que julga inopinado? Simplesmente porque o corpo-si desse pedreiro, seu sistema auditivo em particular, incorporou uma condensação de história, profissional, social, local, que o levou, sem um tempo de deliberação determinável, a um agir industrioso e socialmente competente (ibid., p. 498).

Poderíamos ainda mencionar a hipótese de Alain Wisner segundo a qual as estratégias óculomotoras eficazes de um trabalhador de uma fábrica de bebidas montada em Bangui por uma empresa do norte da França (caso típico de transferência de tecnologia) pudesse recorrer, não, claro, a uma familiaridade com indústrias de processamento de que não podia dispor culturalmente em sua bagagem, mas a uma disponibilidade de vigilância e de síntese de dados sensoriais não vinculados diretamente com o objeto a cuidar, culturalmente incorporada por práticas imemoriais de caça e pesca (cf. ibid., p. 651-652).22

$\mathrm{O}$ fato de esse encaixamento ao mais profundo do "escondido no corpo" se articular com valores de coordenação de ordem social poderia ser ilustrado por exemplo pelo conceito de "unidade composta de ação", forjada pelo ergônomo Bernard Pélegrin a propósito de seu notável estudo sobre a Direção Operacional de triagem de mercadorias da SNCF (estatal francesa das ferrovias). De que maneiras os 6 agentes que atuavam nessa Direção ajustavam de modo síncrono as decisões operacionais a tomar a partir de fontes de informação heterogêneas e que envolviam coletivamente o modo de escuta e de tratamento das seguintes - a partir de uma continuidade diacrônica de informações recebidas, a ser consideradas ou descartadas, informações vindas tantos das Direções Operacionais de todas as outras agências de triagem do território nacional como de microeventos locais, e que diferiam de acordo com as responsabilidades funcionais próprias dos agentes? Pélegrin fala da "dimensão coletiva da atividade individual", uma forma de considerar e integrar "a necessidade, para a atividade individual, de manter-se ajustada (sem "folga" para manter o andamento) ao conjunto produzido sincronicamente pelo conjunto 
de colegas". Trata-se da metáfora de uma orquestra sem maestro: a ausência de alguém que mantenha uma permanente "sincronia diacrônica" só podia ser suprida por uma atenção fluida mas sensível aos intercâmbios telefônicos dos outros, aos tons de voz, mímica e gestos, deslocamentos - todos eles pistas a integrar no momento em que ocorrem, incorporadas por um corpo-si, pistas que só ocasionalmente chegam ao nível da reflexão e da linguagem, adequadas para dar uma dada inflexão à recepção e tratamento da informação da parte de cada um dos protagonistas dessa direção operacional. ${ }^{23}$

Essa dimensão do encaixamento nos parece resultar de estudos históricos que tentamos fazer sobre a história do conceito de atividade. Propusemos um resumo quando de uma solicitação de contribuir para o levantamento de teorias da atividade no Congresso da International Ergonomics Association, em Maastrich, em julho de 2006 (ver a nota 15 acima). Perguntamo-nos em que circunstâncias aparece o conceito de atividade em textos de alguns grandes filósofos (tentando levar em conta a língua na qual expunham). A atividade no sentido ergológico pode ser concebida como a tentativa de unir a instrução dos dois lados que acreditamos ter distinguido nessa história: seja o que se interroga sobre o agir humano visando à produção de saberes (cujo modelo foi por muito tempo a matemática) e aquele que se interroga sobre as condições de possibilidade do fazer industrioso. Nos dois casos, quer se trate de tentar produzir um conceito ou de tentar produzir um meio de vida em conformidade com nossas normas de saúde, a tentativa de compartimentar faculdades, recursos, potências específicas, torna-se impraticável, e vem um momento em que é preciso "rejuntar" as partes, prontos a sacrificar a preocupação com o claro e distinto àquilo que visa a compreender nosso agir. É inaceitável a separação radical do que seria do polo do corpo biológico e o que seria do polo da "substância pensante" (para usar uma expressão cartesiana). A atividade humana, uma vez que passou a ser tematizada como tal (como em obras de Kant) e, ainda hoje, tal como funciona na linguagem ordinária fora

\footnotetext{
${ }^{23} \mathrm{Cf}$. Pour passer le triage au crible, le projet ETNA à la SNCF, Rapport de Recherche du Centre «Culture, communication et Forces Productives» (hoje equipe de Ergologie do CEPERC-CNRS, Université de Provence) et a sociedade ACTIVITÉ, Grenoble, 1988. E, publicado em ERGOLOGIA, n.5, Bernard Pélegrin, « Sur 1'auto confrontation: vous avez dit «croisée »? » [Sobre a autoconfrontação. Você disse "cruzada"?]. Cf. tb. a importante obra recente de Alexandra Bidet (2011, p.317 s.: («Au principe d'une niche écologique : une division tacite du travail ») ["No princípio de um nicho ecológico: uma divisão tácita do trabalho"]. Quando há um maestro, persiste ainda assim toda uma série de ajustes surpreendentes para o iniciante: ver a dissertação Ingêniérie de la formation et des compétences (Université de Strasbourg, Sciences de l'Education), de Claire Hollenstein: Le corps-soi du musicien: recueil des entretiens, orientanda de Louis Durrive (2008-2009).

24 Vergnaud, toma como exemplo, para explicitar o conceito de esquema, a organização e o desenvolvimento de gestos do atleta de salto com vara Bubka (1996, p. 279).
}

das noções mais elaboradas da ergonomia, da psicologia histórica, do pragmatismo americano, sempre remete, sem que isso costume ser tematizado no sentido dessa necessidade de rejuntar as partes, de pensar a unidade da entidade, matriz de nosso esforço de viver (e que chamamos de corpo-si).

Disso decorre a caracterização parcial da atividade no sentido ergológico: sinergia problemática e enigmática dos heterogêneos que há em nós. Problemática porque, como se disse, nada garante seu sucesso, seu grau de viabilidade e de felicidade. Enigmática porque, na condição de crisol desse encaixamento: nenhuma disciplina pode circunscrever a hierarquização de circuitos e de temporalidades prodigiosamente distintos, mas que ainda assim devem ser parcialmente coerentes entre si, por mais heterogêneos que sejam, como é o caso da sinergia dos ingredientes 1 e 2 da competência (e, por isso mesmo, do 3). Não há estatuto do corpo-si sem recurso a pesquisas cooperativas e indefinidas sobre esses encaixamentos que ligam enigmaticamente os recursos e limites próprios de um corpo biológico a um - obscuro - mundo de valores.

Não surpreende, nessas condições, que os esforços intelectuais visando a descrever a sinergia momento a momento entre nossos recursos especificamente corporais, subordinados a valores de uso de nossa vida, como o é o modo de engajamento numa prática esportiva, sejam um dos domínios mais avançados em termos de encaixamento. ${ }^{24}$ Sentimos quanto a isso uma enorme convergência entre nossas propostas precedentes e as noções apresentadas no texto de Récopé et al. 2011 a propósito de, por exemplo, uma "estrutura total" (seção 5), cujos "atos, percepções, sensações" se mostram como "atualização contextual, em diferentes momentos e de acordo com as diferentes circunstâncias do jogo" (tratase de uma pesquisa sobre a prática do vôlei por grupos de jovens, cf. RÉCOPÉ, 1996; FACHE, 2011). Mesmo a tão estimulante ideia de que a "sensibilidade a", a que exprime a norma prevalente do agir, "corporifica", ou seja, "constitui o corpo dos praticantes": as sensações subsumidas por essa norma prevalente na relação com o jogo, de início "focalizadas não mãos" (para a recepção da bola) migram para o conjunto do corpo, "induzindo a criação de novas posturas, forma de apoio e propriocepções, bem como outras formas de mobilização corporal" (seção 6). A sensibilidade a, assimilada a um transcendental, instaura uma "ordem fenomênica constituída no curso de uma história individuada de atividades e experiências" (ibid.)

\section{Corpo-si: ser e história}

O uso de si no trabalho, a dramática do uso de um corpo-si, a definição dessa dramática como um debate 
de normas, o corpo-si como encaixamentos de debates de normas de que resultam incessantes renormalizações de todos os níveis constituem um itinerário que, é inútil ocultar, leva a deparar com espinhosas questões que outros pesquisadores tentam abordar de maneiras diversas, mais ou menos próximas da nossa.

Podemos resumir essas dificuldades da maneira abaixo, partindo da assunção da atividade humana como encaixamento de debates de normas.

- Quem diz "debates de normas" convoca uma dimensão axiológica que está no próprio princípio de todo agir humano. Entre as normas antecedentes e as dimensões locais do impossível/invivível, o debate só pode ser resolvido com referência a um obscuro mundo de valores. Ao mesmo tempo, as renormalizações que disso resultam mobilizam o sujeito a pôr em jogo saberes. A parte post, sem dúvida: como o diz Pastré, referindo-se a Rabardel e Samurçay, "provavelmente não há atividade humana que não comporte uma parte de aprendizagem" (2005, p. 232). É porém impensável que, a parte ante, o ato de renormalização não se processe sem recurso ao "inventário de saberes" de que cada pessoa dispõe no momento. Louis Durrive, retomando nossa hipótese do triângulo ValoresSaberes-Agir, o recorda: "Porque a norma tem duas fontes: os saberes e os valores". Não há renormalização sem que "aquilo que sei de modo geral sobre a situação a gerir (os saberes do métier, da organização)" venha "encaixar-se com aquilo que sei especificamente acerca dessa situação" (2010, p. 31). Há assim uma dialética permanente do ante e do post, uma dimensão que se poderia chamar de epistêmica. Logo, a primeira questão nos remete a uma dualidade entre o axiológico e o epistêmico que há no cerne da atividade humana.

- Mas falamos de encaixamento: se é difícil pensar dar conta das relações diferenciadas com esse mundo de valores que todo debate de normas envolve em seu próprio nível, parece bem mais claro que cada nível do debate de normas mobiliza formas e modalidades de saber sobremodo diferenciadas. Seria possível nomear, categorizar e hierarquizar essas formas de saber, umas mais próximas do polo do que denominamos "aderência", que remete à necessidade de travar um debate na imediaticidade do agir mais local, e as outras inscritas, pelo contrário, em debates travados em intervalos temporais bem mais amplos? A segunda dificuldade nos remete portanto à natureza epistêmica dos diferentes saberes, à homogeneidade, suposta mas problemática, do termo saber para cobrir esse possível continuum.

- A terceira dificuldade refere-se às perplexidades sobre esse estranho ser que é tanto um poder de acumulação, de estabilização das aquisições de sua história (suas "renormalizações") como um ser disponível para responder continuamente aos debates de normas do agir, debates que podem desnormalizar (sic) o que se achava estável. O que deve subsistir em nós para que aquilo que permanece possa transformar-se? ${ }^{25}$

Como vimos, não pode haver em nenhum momento da vida uma tabula rasa, nem no eixo axiológico (a existência de projetos-herança de diversas temporalidades) nem na dimensão epistêmica (de acordo com seu grau maior ou menor de "aderência" a situações, os diversos saberes devem mais ou menos instrumentar as renormalizações em função do nível de singularidade das situações novas, concebidas e com as quais lidar). Ainda mais sinteticamente: essas dialéticas transformadoras, ao mobilizar inextricavelmente o axiológico e o epistêmico, devem poder se sedimentar para legitimar uma pessoa. Mas esse ser enigmático, ao mesmo tempo, não está livre para parar de "fazer história" (mediante suas renormalizações) e, portanto, para não ser transformado, mesmo de maneira infinitesimal, pelo seu próprio poder reconfigurador.

Trata-se do antigo problema filosófico do mesmo e do outro, no âmbito do qual, para falar em termos aristotélicos, do substrato da mudança, da tão delicada articulação, no ser vivo humano, entre ser e história. ${ }^{26}$

Quanto a essas três grandes questões maiores, vamos apenas evocar alguns pontos vitais para dar continuidade aos fecundos debates que já vimos travando.

3.1 A primeira dificuldade é muito bem apresentada, a nosso ver, por Récopé et al., em seu levantamento, com a noção de "complementaridade norma-esquema" (2011, seção 8). O esquema remete mais à dimensão epistêmica $\mathrm{e}$, as normas, à dimensão axiológica, mediante as relações normas/valores: "Do ponto de vista da ergologia, pensar na ação não é apenas uma obrigação advinda do meio, mas também um imperativo da saúde. Vemos aqui a dupla leitura: atividade intelectual e atividade vital. O esforço de saber é também um esforço de viver" (DURRIVE, 2010, p. 37). Essa tensão dual traz uma questão antropológica: apresentamos a hipótese de uma origem "fusional" entre esses dois tipos de desaderência e do caráter passavelmente

\footnotetext{
${ }^{25}$ Essa questão é por vezes resolvida por uma distinção hipotética entre atividade e subjetividade. Mas se o corpo-si se acha infiltrado no seu âmago mais profundo por "projetos-herança", como se poderia distinguir nele o que é processo de atividade no seio de um receptáculo que seria o da subjetividade? Isso leva a pensar na antiga personagem que, decidida a beber a água do mar, mas não a dos rios, exigia que se impedisse os rios de correr para o mar antes de se submeter à prova (segundo Joseph Bertrand, cf. SCHWARTZ, 2000, p.133). [A parte post: posteriormente; a parte ante: anteriormente. N.T.]

${ }^{26}$ Não surpreende que, no âmbito de um doutorado em filosofia (Stéphanie Mailliot, Département d'Ergologie d'Aix-en-Provence) se tenha firmado uma Convenção CIFRE [convenção industrial de formação para a pesquisa, vinculando um laboratório universitário, uma empresa e o Ministério da Educação] com o Observatoire Régional de Métiers de Marselha sobre a questão da mobilidade profissional: como no caso das "transferências de competência", cabe pensar num substrato capaz de assimilar e se recompor.
} 
dramático, no que se refere ao governo humano e, mais particularmente, do trabalho, de uma assunção de independência da desaderência epistêmica em sua relação com a desaderência axiológica"27 (SCHWARTZ, 2009, p. 61 ss.). Não vamos desenvolver aqui o que é uma hipótese a explorar; basta observar que essa dualidade está presente para quem se ocupa há muito tempo de pesquisar o trabalho como matriz de aprendizagens.

É o caso da distinção de Rabardel entre sujeito capaz e sujeito epistêmico (2005, p. 12). Aquele visa a intervir no mundo, ao passo que este visa em primeiro lugar produzir saber. Embora essas dimensões não sejam separáveis, Pierre Rabardel sustenta a proeminência do sujeito do agir: "Enfatizar o sujeito capaz é parte do movimento de reequilibração dos conhecimentos psicológicos sobre a atividade humana em situação natural” (ibid, p. 13).

Parece-nos bem próxima dessa dualidade a distinção de Pastré entre "esquemas de ação", cujo determinante essencial é que a situação requer, para ser tratada, esquemas e instrumentos, o que se situa no epistêmico, e "esquemas de atividade", via a relação normas próprias/ valores, mais ligada ao axiológico, na medida em que se trata do "sujeito, com sua história, experiência, seu mundo de pertencimento", logo, com suas escolhas de si mesmo, que orienta suas estratégias (2005, p. 105-106 e 232). Mas, como no caso de Rabardel, quando retoma daquele a distinção entre atividade produtiva e atividade construtiva, Pastré, afirmando que não são indissociáveis, alega que "a aprendizagem (situada na atividade construtiva) sempre ocorre no curso de uma atividade produtiva (no sentido amplo): "O sujeito se constrói enfrentando o real: é esse o sentido [...] que se pode dar ao par atividade produtiva/ atividade construtiva" (ibid., p. 232), havendo, mais uma vez, a preeminência da primeira.

O conceito de esquema, utilizado fecundamente por essa corrente da didática profissional, vem de uma longa elaboração de Gérard Vergnaud, sendo um "conceito chave para pensar as relações entre os saberes voltados para o agir e os saberes teóricos" (1996, p. 278). Trata-se de um conceito que tenta pensar uma propriedade específica da linguagem, porém mais geral que ela mesma, porque essa propriedade pode atuar também no nível infralinguístico: a invariância e a adaptabilidade em geral. Se, como ele diz, há, no "fundo da ação a conceituação" (ibid., p. 275), logo, uma dimensão epistêmica no cerne do agir, a seu ver é ainda assim preciso devolver ao conhecimento sua função primeira, uma função de ação no e sobre o real: "O pensamento começa pela ação". Se, nos termos de Récopé, "a conceituação parece assim atualizar a sensibilidade $a$, ao mesmo tempo em que a sensibilidade $a$ resulta de uma conceituação", nem por isso deixa de ter destaque o que chamamos eixo axiológico: “Tem-se por fim aqui o problema do advento do valor, que remete ao problema da discriminação das qualidades" (RÉCOPÉ et al., 2011, seção 7, parte final).

Mesmo que as distinções aqui evocadas nem sempre correspondam perfeitamente as que caracterizamos como sendo eixo axiológico/eixo epistêmico no nível mais profundo da atividade, constatam-se convergências e possibilidades compatíveis a explorar. Se houver alguma distância a tomar dessa primeira dificuldade, sua formulação poderia ser: qual a natureza dessa enigmática preeminência da atividade, do agir transformador? ${ }^{28}$ Essa natureza é da incidência do axiológico sobre o epistêmico, uma vez que toda atividade, como debate de normas, remete o real a transformar a valores (como diz Canguilhem). Com relação à prioridade dada ao esquema por Revault d'Allones, Récopé e al. lembram ainda que, segundo Canguilhem, essa prioridade era atribuída às normas próprias, acrescentando que "não se pode entender a ação de um organismo sem considerar a noção de normas próprias", que são as únicas a permitir dar conta de seus comportamentos privilegiados em situações comparáveis. Para a abordagem ergológica, a dimensão antropológica da vida se inscreve na problemática do "conceito e da vida", em que é esta que, em última instância, utiliza o saber para ampliar seu campo de fruição da vida: "O esforço de viver retoma continuamente o esforço de saber, apossa-se dele de algum modo para lhe transmitir sua energia e, assim, multiplicar suas possiblidades" (DURRIVE, 2010, p. 40).

Contudo, sendo essa exigência do viver, como busca de saúde, algo presente no âmago do agir, só é possível definir este último como debate de normas encetado por um corpo-si singular diante de um meio ecológico, humano, social. Há assim uma dimensão dramática (no sentido primeiro) da atividade que inscreve desde o começo a dimensão epistêmica nos contextos de seus debates. Não pode haver abordagem da dimensão epistêmica que não mergulhe na dimensão local dos debates de normas. ${ }^{29}$ De fato, a dimensão epistêmica, na medida em que é mobilizada pelos debates de normas, em que ocorrem de modo problemático, muitas vezes conflituoso e contraditório, as escolhas de vida coletiva, não pode emergir na neutralidade. Nossas sociedades se acham saturadas de normas de vida social, de organização, prescrições e procedimentos que se exprimem na forma específica de saberes que, pode-se dizer, vêm "em

\footnotetext{
${ }_{27}$ Deve-se falar de desaderência axiológica na medida em que, exceção feita a um egocentrismo radical, a influencia de um mundo de valores sobre nós nos ressitua num horizonte de comunidade humana que va além de nós em variados graus (cf. SCHWARTZ, 2009, p. 64-66).

${ }^{28} \mathrm{Cf}$., sobre essa entrada problemática via saber em detrimento do agir na sociologia do trabalho, Alexandra Bidet, op. cit., p. 42.

${ }^{29}$ Essa exigência se inscreve no que denominamos disciplina ergológica (SCHWARTZ, 2000a) e envolve em parte o que chamamos de dispositivos dinâmicos de três polos como postura de abordagemde toda situação de atividade humana (cf. SCHWARTZ e DURRIVE, 2009, p. 262-263).
} 
linguagem", ou melhor, "em conceitos". A separação entre a dimensão epistêmica e a axiologia, necessária quando o foco são objetos naturais, pode vir a ser, aplicada ao agir humano, uma restrição indevida da atividade, uma negação de suas dramáticas, uma desconexão de suas sinergias esforço de saber/esforço de viver, para pôr em lugar disso um saber produzido às cegas (em desaderência) com referência a suas dramáticas.

Diante da inevitável e recorrente instabilidade dos debates de normas inerentes a todo agir, tornar invisível o que alguns denominam "saberes de ação" (nossos "saberes investidos", ou melhor, saberes "próximos do polo da aderência"), associado ao uso controlado ou inconsciente da "má aderência" cf. DURRIVE, 2010, p. 35) - o que chamamos de "usurpações" (no sentido em que Canguilhem falava de "a usurpação da norma", 1966, p. 91) - é o risco permanente que ameaça essa dialética epistêmico/axiológico. Por isso não é possível tratar dessas duas dimensões indissociáveis da experiência humana independentemente das tensões que a atravessam em nossa história. Eis uma forma moderna das relações saberes/ poderes: ela imprime uma historicidade essencial nessa dualidade normas/esquemas e nos obriga a considerá-la devidamente quando desejamos intervir em nosso presente.

3.2 A segunda dificuldade vincula-se com o levantamento e descrição "dos" saberes, uma vez que não há agir sem formas de saber. Trata-se de uma questão eminentemente epistêmica, e mesmo claramente epistemológica: haverá em todas essas formas de saber alguma homogeneidade ou seria possível categorizar distintos estatutos para elas?

O desafio vem da tese de Vergnaud, no início de seu texto já citado: "No fundo da ação está a conceituação". Se no começo está a ação, se esta inclui "a obtenção de informações sobre o ambiente, o controle dos efeitos da ação [...], a eventual revisão da organização do comportamento", então "para dizer tudo, nada seria possível sem a conceituação". E seu artigo se propõe a demonstrá-lo "com exemplos advindos de inúmeros registros da atividade humana" (p. 276). O conceito de esquema permite reunir o conjunto de formas dos saberes mobilizados no agir. Já dissemos como esses estudos de psicologia cognitiva nos serviram para suprir zonas de que falamos mas exploramos insuficientemente (por exemplo, a noção de "saberes investidos").

Mas, além do risco da neutralização parcial dessa atividade de conceituação (sua modalidade de surgimento) evocado acima, a questão, para a qual não temos resposta estabilizada, seria: como combinar o pensamento via esquemas com a tese do encaixamento do debates de normas? Retomemos o exemplo dos vínculos possíveis entre memória de trabalho e memória no trabalho: se há esquema na manutenção da memória instantânea, no seio do lobo frontal (vindo alguns índices preferenciais do ambiente, em função de certas disposições da ação de certo modo reunidas como patrimônio por estar ligadas a certo tipo de relação interessada com o ambiente de trabalho) esse esquema de "colocação em memória", intrínseco à competência no trabalho, só pode ter a nosso ver esse estatuto em termos incoativos. ${ }^{30} \mathrm{O}$ grau de singularidade e de integração nos circuitos infraconscientes do corpo afasta esse "esquema incoativo" do paradigma da conceituação. Nem por isso perde ele uma função microorganizadora do agir vigilante, capaz de gerir encontros parcialmente inéditos no âmbito de um micro-horizonte de similaridades operatórias.

Parece-nos assim que essa dimensão das estruturas organizadas, ou organizadoras do saber, vinculada com os diversos registros do agir, tem de ser sempre tratada de modo tendencial para que não se percam de vista os encaixamentos no corpo-si. Esses saberes mais ou menos "Investidos", esses conceitos "para a ação", operatórios ou pragmáticos (cf. PASTRÉ, 2005, p. 234) nos parecem situados entre o polo dos esquemas "incoativos" e aquele no qual a atividade conceituadora gera verdadeiras estruturas de saber capazes de exprimir suas normas de constituição interna. Tudo depende do grau de aderência ou desaderência relativas à situação a tratar, ao tipo de decisão operatória a tomar em cada nível do debate de normas, havendo um encaixamento entre esses diferentes níveis a depender das formas de convocação pelos graus de aderência ${ }^{31}$ (pode-se pensar que mais de uma dessas dimensões da situação a tratar se aproximem da instantaneidade, da aderência extrema quanto mais "incoativo", infraconsciente, for o esquema).

Uma segunda observação se associa a esta: a questão da “colocação em linguagem" desses saberes. Quanto mais os textos estimulantes no campo da corrente da didática profissional se ocupam - sua ambição pedagógica é essencial na origem - da retomada "na escola" (PASTRÉ, ibid., p. 233) das aprendizagens geradas na atividade produtiva, ${ }^{32}$

\footnotetext{
${ }^{30}$ Quando distingue na aprendizagem do controle de centrais nucleares em simulador um modelo operacional, pragmático, de um modelo cognitivo, no registro epistêmico, Pierre Pastré tem a preocupação de dizer que "há conceituação nos dois domínios" (2005, p. 75). O conjunto do artigo, La conception de situations didactiques à la lumière de la théorie de la conceptualisation dans l'action [A concepção de situações didáticas à luz da teoria da conceituação na ação] (ibid., p. 74-107), é essencial para a discussão desse ponto.

${ }^{31}$ Quanto aos profissionais de controle das centrais, Pierre Pastré diz que "esse comportamento no cotidiano é uma mistura inextricável de modelo operacional bem adaptado e rotinas que se constroem num nível superior, para tornar a atividade mais automatizada e menos custosa" (ibid., p.94).

32 Ver p. ex. as práticas de "debriefing" desenvolvidas por Pastré (ibid., p. 83, 89, 96) e a tão precisa proposta de Gérard Vergnaud: a conceituação subjacente à ação "nem sempre basta a si mesma", sendo "profundamente transformada quando explicitada, debatida e organizada num sistema coerente de conceitos e enunciados, ou seja, quando assume forma teórica" (op. cit., p. 275).
} 
tanto mais a questão da linguagem, de suas derivas, nos parece formulada sem muita clareza. ${ }^{33}$ Qual a relação entre conceituação, do epistêmico, da formulação teórica, com os recursos, formas e armadilhas da linguagem? Vamos nos limitar a dois pontos para um debate futuro.

Se há encaixamentos, "esquemas incoativos", infiltração de projetos-herança no mais íntimo do corpo-si, há forçosamente limites imprecisos, imprevisíveis, à "colocação em palavra" (ao "debriefing") dos esquemas que organizam o agir, apresentando-se ainda todo tipo de consequências operacionais incidentes na determinação de competências e no controle da atividade (industriosa).

Por outro lado, os processos de usurpação acima aludidos passam por verdadeiros "assaltos" do uso de noções e conceitos de estatuto ainda indefinido. A tensão no ambiente de desconexão entre a dimensão epistêmica e a axiológica passa por um uso desviante da conceituação, ocultando as dramáticas da atividade. A linguagem é o elemento no qual ocorre o real drama, sendo por isso que a colocação em linguagem, principalmente em situação de trabalho, nunca é uma operação neutra.

Terceira observação: Assim como há uma continuidade - "imprecisa", inidentificável - na colocação em linguagem do lado dos "esquemas incoativos", do mesmo modo parece epistemologicamente necessário admitir uma descontinuidade no outro polo, a que procura se mover na desaderência, que busca "fabricar conceitos". Como Gérard Vergnaud diz com acerto, "Os conceitos e teoremas mudam de estatuto ao serem expressos, discutidos, integrados em sistemas teóricos coerentes" (ibid., p. 289). Mas essa afirmação vem em apoio de uma continuidade de fundo com a "linguagem ordinária", base de toda construção conceitual, na medida em que é nela que se podem identificar as invariantes, os esquemas. Quanto mais a problemática evocada das relações entre conceito e vida legitima uma visão homogênea das ambições de conhecer relativa à ambição de viver, tanto mais a própria eficácia dessa ambição de conhecer exige, para a forma de produção de conhecimento que é a ciência, um esforço de descentração com respeito à ambição de viver (a "boa desaderência"), ou seja, com relação ao que chamamos dimensão axiológica. As "usurpações" são possíveis justamente porque buscam recuperar ilegitimamente o benefício e prestígio dessa descentração legítima. Explicando o que chamamos de "má desaderência", tentamos em várias circunstâncias justificar o que se poderia denominar "entrada em epistemicidade", ou seja, um uso estritamente regrado de conceitos no âmbito de um "referencial conceitual", em oposição aos usos mais frouxos de palavras comuns e usos mais livres daquilo que se pode chamar de "noções". Já diferenciamos vários tipos de epistemicidade, o que permite em seguida traçar uma topografia de circuitos ilícitos em seu âmbito. ${ }^{34}$ A continuidade das formas de saber não deve hipotecar a "boa desaderência", e isso introduz uma descontinuidade no contínuo de saberes articulados a todo agir transformador.

3.3 A terceira questão foi formulada a partir de nosso diálogo com os autores precedentes: as pesquisas sobre as dinâmicas da aprendizagem (epistêmica) geradas no curso das atividades profissionais os leva a deparar num certo momento com o enigma, ou a entidade-sujeito, como o lócus de sedimentação de um patrimônio, sem dúvida instável, mas ainda assim capaz de lidar em seu âmbito com múltiplas variabilidades.

Os esquemas, diz Vergnaud, se "desenvolvem em interação", formam "repertórios", abrindo-se a uma variedade de domínios da atividade. Mas "esse desenvolvimento ocorre na maioria das vezes na duração longa da experiência" (ibid., p. 284). Janine Rogalski (2009) distingue entre experiências "sedimentadas" e experiências "episódicas" que se podem "articular". 35 A noção de experiência sedimentada, instância de organização de novas experiências, se inscreve numa temporalidade longa e, sendo "história incorporada", é aproximada por Janine Rogalski da noção de habitus de Bourdieu (seção 2). Rabardel, distinguindo "capacidades e poderes", tanto aquelas como estes "centrados no sujeito", os inscreve em "dinâmicas temporais distintas": "A atividade construtiva (mediante a qual se elaboram as capacidades de fazer e agir do sujeito) deve, para além das variabilidades da singularidade, elaborar as invariâncias necessárias à renovação e desenvolvimento das capacidades de agir do sujeito em vir-a-ser" (2005, p. 20). Todos esses trabalhos se aproximam com insistência, como é lógico, de uma entidade sujeito enigmática. Pierre Pastré o exprime com notável vigor, ${ }^{36}$ com sua retomada de distinção de Paul Ricoeur entre idem e ipse: "Para se autoconhecer, o si deve se reconstituir a partir de suas obras, de todos os traços de si mesmo que deixou em seu viver [...]. A permanência no tempo mistura inextricavelmente algo que é da ordem da acumulação e que advém da mesmidade [idem] e algo que é da ordem da fidelidade a si mesmo e advém da ipseidade [ipse]" (2005, p.241). Diante da mesma temática da mudança e do mesmo, Michel Récopé et al. falam do "corpo do ser-praticante" como um "corpo que se altera à medida que incorpora outra norma de atividade e constitui um

\footnotetext{
33 Segundo Gérard Vergnaud (op. cit., p. 289), "É difícil colocar em palavras conhecimentos em ato". Claro que sim, mas é essencial explicar por quê.

${ }^{34}$ Para uma breve apresentação, cf. SCHWARTZ, 2010, p. 17.

35 "Pode-se dizer que as experiências remetem ao contínuo da experiência e, as experiências episódicas, à discretização, e mesmo à ruptura. Os dois processos têm sua função no desenvolvimento, bem como nas situações didáticas que buscam produzi-lo ou orientá-lo" (2009, seção 6.3).

36 Como observamos em nossa intervenção em Dijon. Cf. 2010, p. 18-19.
} 
novo mundo. Isso nos parece garantir uma integração corporal, totalmente contrária a uma dispersão"37 (2011, "Conclusion").

Constata-se assim uma convergência dessas pesquisas sobre aprendizagem oriunda do fazer na exigente interrogação sobre essa entidade que suporta o mesmo e o outro. ${ }^{38}$ De igual forma, percebemos uma convincente tentativa de redefinição do conceito de experiência, vista como inclinando-se na direção de uma mesmidade, sedimentando integrações sucessivas e, por isso, disponível para episódios sucessivos a ser tratados que a vida oferece.

Esses mesmos autores não escondem as dificuldades de articular, como disse Janine Rogalski, experiência sedimentada e experiência episódica: uma mistura "inextricável", disse Pastré: "recuperar aquilo que, no desenvolvimento, vem de um ou do outro registro é um empreendimento sobremodo difícil, porque em geral essas duas dimensões se interseccionam ao ponto de se confundir" (ibid., p. 241). Adiante, na seção 6.3, essencial nessa contribuição para "Gênese e Identidade", ele menciona duas aporias, a nosso ver bem próximas entre si: a do "lugar do sujeito na história (sua história) e a da natureza da invariância no processo histórico" (p.252). Distinguindo nesse ponto o sujeito do "si", ele lembra ser necessário "vencer a dispersão de uma vida para fazer dela um destino", 39 obrigação mais difícil de tornar inteligível porque toda existência humana é feita também de "rupturas", em vez de ter apenas continuidades (p. 253). Há "escolhas" a fazer, não sendo o ser humano um "fantoche" de sua história nem da história: "é imperativo lembrar que não haveria sujeito sem transcendência com respeito aos organizadores de sua atividade" (p. 259).

Páginas sobremodo belas, de cuja inspiração essencial partilhamos. ${ }^{40}$ Mas não seria possível avançar mais nessa questão? Onde e como se processa essa mistura

\footnotetext{
37 Quanto a isso, Hartmut Rosa (op. cit., p. 179), observa, com Walter Benjamin, e Georg Simmel, a progressiva "perda da experiência" decorrente de uma aceleração de "episódios" não cumuláveis, não integráveis.

${ }^{38} \mathrm{Um}$ movimento que muito apreciamos, mais fecundo, ao nosso ver, do que todo movimento inverso, que parta "do sujeito" (indiferenciado, que enfrenta o quê?) com relação a "suas obras". Sobre esse movimento, cf. PASTRE, 2010, p. 52-55 (Faut-il un sujet pour le pouvoir d'agir?, p. 53). O mesmo tipo de movimento nos levou da atividade de trabalho ao que redefinimos como "uso de si", logo, a essa enigmática "entidade-sujeito" (cf. acima, parte 1).

39 Nesse mesmo sentido, falamos em nossa tese (1988), e também referindonos ao trabalho, de "destino a ser vivido".

40 Este foi na verdade o argumento essencial de nossa tese.

${ }^{41}$ A experiência só é formadora na medida em que leva ou obriga a debates de normas. Quando Janine Rogalski cita o pesquisador sueco Brehmer, de acordo com o qual "a experiência não resulta do simples acúmulo de casos, mas de um processo ativo de testar hipóteses", e "...temos necessidade de definir o que temos a aprender antes de ser capaz de aprendê-lo" (op. cit., seção 5,1 ), vemos nessa dimensão ativa da experiência uma proximidade com a distinção que fizemos entre "experiência do trabalho" e "trabalho como experiencia" (SCHWARTZ, 2000, p. 333-337).
}

"inextricável" do mesmo e do outro, de nosso idem e de nosso ipse? Diríamos, para concluir, que lançar um olhar sobre nosso destino de seres humanos como seres de atividade é nos ver como cadinhos, na condição de corpos-si, de sucessões de debates de normas encaixados. Parece-nos ser precisamente nessas junções que ocorre de modo incessante essa articulação "inextricável". Os debates de normas nos parecem como escansões em que se tentam realizar as articulações. Os debates de normas são umas quantas obrigações de escolher, de contextos e de visibilidade extremamente variáveis.

A mesmidade está massivamente presente, mediante o confronto com as normas antecedentes, mesmidade histórica, social, e mesmidade na substância do impossível/ invivível da pessoa que se alimenta de miríades de suas próprias renormalizações, as quais se acham sedimentadas em seu corpo-si. Para cada pessoa, o debate de normas traz uma parcela de inevitável singularidade, o que faz dela "uma pessoa", em razão da história própria de suas sedimentações. Porém, ao mesmo tempo, eles se recolocam a cada momento da vida em termos relativamente mais ou menos novos, ainda que esse novo tenha pertinência infinitesimal (recordemos o antigo postulado da análise do trabalho, que herdamos dos ergônomos: toda situação de trabalho é sempre parcialmente singular). Logo, há sempre, mesmo na invisibilidade, a obrigação de escolher de novo (as "rupturas" evocadas por P. Pastré). Os debates de normas reativam nossa ipseidade, obrigam o sujeito a se reescolher como "si", questionam as "fidelidades" e levam o sujeito a retrabalhá-las em alguma medida. O fato de a continuidade de nossa vida se escandir mediante dramáticas, de ser concebida como nada mais do que uma sucessão de dramáticas, explica como elas deixam traços, imprimem-se no corpo-si, devem permanentemente negociar sua compatibilidade como a experiência anterior de vida, concebida como tentativa sempre renovada de tornar-se coerente com as renormalizações precedentes. Por isso, ainda que de modo infinitesimal, a mesmidade é sempre retrabalhada. ${ }^{41}$ Diante dessa grande dificuldade, dessa aparente aporia, essa mistura inextricável de variação e invariância, de identidade do "si" e de sua permanente inserção na história, a proposição da vida humana como sequências indefinidas de debates de normas encaixadas de um corpo-si nos parece trazer alguma luz. Esses debates de normas constituem por assim dizer o coração pulsante da dialética idem/ipse. A atividade faz história. E nada podemos fazer contra isso, restando-nos o desafio, dia após dia, de assimilar esses novos encontros no ser no qual viemos a ser, e sem garantia de sucesso.

Por conseguinte, o destino do humano, como ser de atividade, é manter-se na tensão constante, e mesmo na contradição, entre desaderência e readerência axiológicas e desaderência e readerência epistêmicas, com o 
risco permanente, sobretudo em nossas sociedades da mercadoria e do direito, de uma divergência patogênica entre essas duas desaderências: risco de ocultamento quanto à necessidade do corpo-si de reformular parcialmente esse destino no presente dos encontros da história, bem como risco de negação quanto à obrigação de renormalizar. Uma obrigação que leva a um retrabalho dos saberes e valores que contesta, recusa, todo conhecimento dominador que essencialmente já sabe tudo.

\section{Referências}

BERTHOZ, A. Le sens du mouvement. Paris: Odile Jacob, 1997. BIDET, A. L'engagement dans le travail, qu'est-ce que le vrai boulot? Paris: P.U.F., 2011.

BOUTET, J. La vie verbale au travail. Toulouse: Octarès Editions, 2008.

CANGUILHEM, G. Le normal et le pathologique. Paris: P.U.F., 1966.

CANGUILHEM, G. Ecrits sur la médecine. Paris: Le Seuil, 2002.

DANIELLOU, F. Développement des TMS: désordre dans les organisations et fictions managériales. Recherche Action Prévention durable des TMS. Communication plénière invitée au 2è Congrès francophone sur les troubles musculosquelettiques: de la recherche à l'action. Montréal. 18 et 19 juin 2008, IRSST/Groupe de Recherche Francophone sur les Troubles Musculosquelettiques. www.irsst.qc.ca "désordre dans les organisations et fictions managériales", 2è Congrès francophone sur les TMS, de la recherche à l'action, Québec, (a)ctivités, 2008.

DI FANTI, M.G.C. Perspective dialogique et approche ergologique: (inter)faces de la relation Langage-Travail. Ergologia, n. 9, 2013.

DURRIVE, L. L'activité humaine, à la fois intellectuelle et vitale, éclairages complémentaires de Pierre Pastré et d'Yves Schwartz. Travail et Apprentissages, 6, p. 25-45, 2010.

FACHE, H. L'expérience corporelle des pratiquants de Volleyball en situation. Phénomènes et structure des apparaissants. Sarrebrück: Editions Universitaires Européennes. Thèse de doctorat en STAPS, soutenue en mai 2010, Université Biaise Pascal, Clermont-Ferrand, 2011.

HOLLENSTEIN, C. Le corps-soi du musicien: recueil des entretiens, Mémoire de master Ingénierie de la Formation et des Compétences. Université de Strasbourg, 2009.

JOUANNEAUX, M. Le pilote est toujours devant, reconnaissance de l'activité du pilote de ligne. Toulouse: Octarès Editions, 1999.

JOUANNEAUX, M. De l'agir au travail. Toulouse: Octarès Editions, 2011.

LAUROUA, S. Les enjeux de la communication non verbale. Mémoire DESS APST, Université de Provence, Département d'Ergologie, 2004.

LEONTIEV, A. (1975). Activité, conscience, personnalité. Moscou: Editions du Progrès, 1984.
MERLEAU-PONTY, M. Phénoménologie de la perception. Gallimard, 1945.

ODDONE, I., RE, A., BRIANTE, G. (1977). Redécouvrir l'expérience ouvrière. Paris: Editions Sociales, 1981.

PASTRE, P. La conception de situations didactiques à la lumière de la théorie de la conceptualisation dans l'action. In P. Rabardel et P. Pastré (Eds.), Modèles du sujet pour la conception (p. 73-107). Toulouse: Octarès Editions, 2005.

PASTRE, P. Genèse et identité. In P. Rabardel et P. Pastré (Eds.), Modèles du sujet pour la conception (p. 231-259). Toulouse: Octarès Editions, 2005.

PASTRE, P. Quel sujet pour quelle expérience: un point de vue de didactique professionnelle. Travail et apprentissages, 6 , p. $46-55,2010$.

PELEGRIN, B. Sur l'autoconfrontation: vous avez dit "croisée"? Revue Ergologia, n. 5, p. 107-145, 2011.

RABARDEL, P. Instrument subjectif et développement du pouvoir d'agir In P. Rabardel et P. Pastré (Eds.), Modèles du sujet pour la conception (p. 10-29). Toulouse: Octarès Editions, 2005.

RECOPE, M. Statut et fonction du schème du duel dans l'organisation de l'action motrice d'opposition: le cas du volleyball. Thèse de Psychologie, Université Paris 5, 1996.

RECOPE, M., FACHE, H., FIARD, J. Sensibilité, conceptualisation et totalité [activité-expérience-corps-monde], Travail et apprentissages, 7, 2011.

ROGALSKI, J., LEPLAT, J. Expériences et expériences. CD-Rom du Premier colloque international de Didactique Professionnelle, p. 2-4 décembre, Dijon, 2009.

ROSA, H. (2005). Accélération, une critique sociale du temps. Paris: La Découverte, 2010.

SCHWARTZ, Y. Travail et usage de soi. In collectif. Je sur l'Individualité (p. 181-207). Paris: Messidor-Editions Sociales, 1987. Republié dans SCHWARTZ, Y. Travail et Philosophies, convocations mutuelles. Toulouse: Octarès Editions, 1992. p. 45-66.

SCHWARTZ, Y. (1988). Expérience et connaissance du travail. Paris: Editions Sociales, Présentation de G. Canguilhem, postface de Bernard Bourgeois, 2012.

SCHWARTZ, Y. Os ingredientes da competência: um exercício necessário para uma questão insolúvel», Educação e Sociedade, v. 19, n. 65, dez. 1998.

SCHWARTZ, Y. Le paradigme ergologique ou un métier de philosophe. Toulouse: Octarès Editions, 2000.

SCHWARTZ, Y. Discipline épistémique, discipline ergologique, Paideia et politeia. In B. Maggi (Ed.), Manières de penser, manières d'agir en éducation et en formation (p. 32- 68). Paris: P.U.F., 2000a.

SCHWARTZ, Y. Un bref aperçu de l'histoire culturelle du concept d'activité, @ctivités, v. 4, n. 2, p. 122-133, 2007. $<$ http://www.activites.org/v4n2Zv4n2.pdf>.

SCHWARTZ, Y. L'ergologie à l'Université de Provence. Revue Industries en Provence, 17, p. 19-30, 2009.

SCHWARTZ, Y. Quel sujet pour quelle expérience? Travail et Apprentissages, 6, p. 11-24, 2010. 
SCHWARTZ, Y. Pourquoi le concept de corps-soi ? Corps-soi, activité, expérience. Travail et apprentissage, n. 7, juin, 2011.

SCHWARTZ, Y., FAITA, D. L'Homme producteur. Paris: Editions Sociales, 1985.

SCHWARTZ, Y., DURRIVE, L. Travail et ergologie, entretiens sur l'activité humaine. Toulouse: Octarès Editions, 2003.

SCHWARTZ, Y., DURRIVE, L. L'activité en dialogues, entretiens sur l'activité humaine (II), suivi de Manifeste pour un ergo-engagement. Toulouse: Octarès Editions, 2009.

SOUZA-E-SILVA, C.; MOTTA, A.R. Le langage et le travailrapprochements entre l'approche ergologique et les études du langage. Ergologia, n. 9, 2013.
SQUIRE, L., KANDEL, E. (1999). La mémoire, de l'esprit aux molécules. Paris, Bruxelles: De Boeck Université, 2002.

TEXEIRA, M. Un lieu épistémologique pour l'analyse de la subjectivité dans l'activité de travail. Ergologia, n. 9, 2013.

VERGNAUD, G. Au fond de l'action, la conceptualisation. In J-M. Barbier (Ed.), Savoirs théoriques, savoirs d'action (p. 275-292). Paris: P.U.F., 1996.

Recebido: 10 de março de 2014.

Aprovado: 04 de abril de 2014

Contato: adail.sobral@gmail.com yves.schwartz@univ-amu.fr 